\title{
The Development of Learning Media Using Interactive Jobsheets For Basic Subjects in Electricity And Electronics Using Psim in Tamansiswa Vocational High School
}

\author{
Nurul Hidayat1 ${ }^{*}$, Bambang Suprianto2 ${ }^{2}$ Eko Hariadi2 \\ 1 Tamansiswa Vocational High School \\ 2 State University of Surabaya \\ *Corresponding author, e-mail: e-mail: nurulhidayat@mhs.unesa.ac.id
}

\begin{abstract}
This study aims to develop learning devices for the subjects of Elementary Electricity and Electronics in class X. As long as learning in class does not provide practical activities, it is necessary to develop learning devices equipped with practical activities as soon as possible. This study uses a 4-D model development model. This study consisted of 2 classes with 1 non-experimental class and 1 experimental class. The rating results show the percentage of $96 \%$ so that it can be concluded that the learning device meets eligibility. The results of sample t-test correlate results obtained are 39.480 , the value of $t$ table is 2.045 . The rating results indicate the percentage of $88 \%$ so that it can be concluded that the learning tool helps students carry out learning activities and practicum. The results of $t$-test on 2 independent samples obtained 4.420, the value of $t$ table is 2.045 .
\end{abstract}

Keywords: Interactive Jobsheet, Practical Learning Model, Practical Skill, Simulation Software

How to Cite: Hidayat, N., Suprianto, B., \& Hariadi, E. (2020). The Development of Learning Media Using Interactive Jobsheets for Basic Subjects in Electricity and Electronics Using PSIM in Tamansiswa Vocational High School, 3(2), 1-12. DOI: https://doi.org/10.12928/joves.v3i2.2532.

\section{INTRODUCTION}

The development of electronic power equipment is growing rapidly along with the development of current industrial technology. Most current use of power equipment in industry must be controlled at all times to obtain the performance of electrical equipment as needed.

Thyristors are semiconductor power devices for use in converter circuits, controlled rectifiers, and ac voltage controllers for industrial applications, for example controlling AC motors, DC motors, heaters, etc. (Tarmizi, 2010).

Because advances in theory and practice of automatic control provide the means to achieve optimal performance of dynamic systems, increase productivity, reduce the hassles of many repetitive manual operations routinely, moreover, most engineers and scientists must now have a good understanding of this field (Ashari, 2012).

Each channel in the information-processing system has a limited capacity - only a number of cognitive processes can take place on a verbal channel at one event, and only a number of cognitive processes can take place on a visual channel at one event (Mayer, 2003).

According to Girwidz (2006, p.104) the ability of students to create detailed problem concepts and integrate interdisciplinary ideas increases. The participants consistently developed knowledge representations for biology, physics, and interdisciplinary content, especially concepts about animal adaptation to thermodynamic phenomena. In our approach, new knowledge is available precisely for memory and for reasoning ability. Generally, students benefit from a hypermedia learning environment.

Meanwhile according to Isman (2009, p.35) it can be said that computers are part of human life. Campus as a place where students and lecturers use computers for research and 
assignments, therefore computers are considered a very useful tool for them. Therefore personal success towards computers, especially between students plays an important role in motivating students and student performance.

According to Nopitasari (2012, p.138) practicum activities require a teaching material that is visually hampered because of the limitations of the instructor, equipment, funding and others so that the process of delivering information is not sufficiently conveyed the lecture method. The learning atmosphere of students will be less conducive and interesting.

According to the research results of Fui-Theng (2014) student learning outcomes are assessed based on the results of the pre-test and post-test by identifying student achievement in the learning environment, showing that the pre-test average score (M) is 47.77 and the standard deviation (STD) is 15.12, indicating that student learning outcomes are below the average value where they do not have certain knowledge to answer questions before they start learning. Then, the post-test results showed an average value of 63.39 and STD of 11.56. These results suggest that student learning outcomes are at a satisfactory level where the average value is above the average value.

According to the results of research from Kurniawan (2012) showed that the average test of student psychomotor learning outcomes in try I was 86.54; students show interest, feel happy, and are motivated in mechatronics lectures.

According to Kirkwood (2014, p.25) changing learning is a complex activity often requiring reconsideration by teachers who are 'teaching' and 'learning'. Requires cuttingedge thinking about the ultimate goal of each intervention, evaluation design and interpretation of results in the context of special education. Future studies need to examine the relationship between these factors and their relationship with potential technologies to change student learning experiences.

According to Sanjaya (2012, p.57) Media is a means of sources of information towards the recipient of information.

According to Musfiqon (2012, p.28) learning media is a physical or non-physical means of liaising between teachers and students to learn effectively and efficiently. Students can receive learning material as a whole and arouse students' enthusiasm for learning.

Multimedia models in learning can help to remember conceptual information better, reduce memory for word by word (rote), and can improve creative solutions for problem solving (Pranata, 2010).

Interactive media offers an alternative teaching medium in the current learning process. Be interactive and discoveries in multimedia learning produce impetus for monotonous passive learning. Instead of being limited by the teacher's steps, individual students step according to the abilities of the students themselves (Belinda Soo-Phing, 2007).

Learning with computers is a presentation of cognitive or psychomotor integrated teaching materials, students can learn more easily. Learning with computers positions the computer as a means of independent learning, students with computers interact with each other according to the design created by the teacher (Rusman, 2012).

Practical activities are learning for students to make observations and authentic experiences from teaching materials, practical activities. Implementation of practicum is realized for conditioned practice. Performance Assessment (Arends, 2008) expects students to carry out specific tasks, for example making essays, carrying out experiments, solving problems, playing music, or painting.

The overall reaction from stakeholders and students was that this type of program is valuable for learning the content. All believed that the final version of the instructional package was easy to use and was a worthwhile learning experience. The match between

\footnotetext{
The Development of Learning Media Using Interactive Jobsheets for Basic Subjects in Electricity and Electronics Using PSIM in Tamansiswa Vocational High School Hidayat, N., Suprianto, B., \& Hariadi, E.
} 
content intended for teaching advanced qualitative research techniques, and teaching strategy (video cases) was considered appropriate (Colon, 2000).

Feedback on the website from post educational games delivery becomes one of the inputs for taking games design to the next level. The Eternal, Synergistic Design Model requires $20 \%$ of dissatisfaction in order to update or change existing design, however, incorporated with LGDM, 20\% is not a necessary indicator and designers continuously do research and improve a game design as needed. The Layers of Negotiation model provided a focus for identifying critical areas and providing sample questions that can guide design (Wiburg, 2017).

Descriptive analysis results can be seen that students have a positive view of the Adobe Flash CS3 learning media by looking at the value intervals that are in the good and very good categories. This means that the resulting media can be used as animation learning media in the Electrical Installation 2 course (Bakri, 2011).

Learning activities for class X students at Tamansiswa Mojokerto vocational high school currently only carry out material delivery on power electronics, practical activities are still not implemented. Students during learning activities only accept basic theories about power electronics without the implementation of practical activities for students, the main obstacle for the implementation of practical activities because some components for practical activities are not available in schools. Practical activities are certainly very important for students to increase students understanding of power electronics and increase student competence in the field of electrical engineering. Considering the condition of learning tools in Tamansiswa Mojokerto vocational high school still does not provide practical activities for students, it is necessary to develop learning tools equipped with practical activities as soon as possible.

So it needs to be made a medium that attracts students to learn power electronics more easily and fun. One way to provide power electronics practices for students is through simulations using a computer with the PSIM application. PSIM can provide students with an accurate picture of the circuits in power electronics and detailed measurement results

\section{RESEARCH METHOD}

This research is a 4-D model development research (Thiagarajan, 1974, p.5). The research model has 4 stages, including define, design, develop, and disseminate. The define stage is the determination about developing interactive jobsheets for power electronics courses. The define stage consists of 5 steps including initial analysis, learner analysis, task analysis, concept analysis and formulating learning goals (Thiagarajan, 1974, p.6). The design phase is the stage of designing a prototype of a learning device equipped with an interactive jobsheet. In this stage the preparation of the Syllabus, Lesson Plan (RPP), jobsheet, and learning media (Thiagarajan, 1974, p.7). The develop phase is the stage of producing learning tools equipped with interactive jobsheets paying attention to the validation results from the validator. This stage consists of 5 steps including expert validation, jobsheet revisions, limited trials, analysis, report generation (Thiagarajan, 1974, p.8). Disseminate stage is the stage of using learning tools complete with a jobsheet on extensive testing. The stage of carrying out the deployment with research reports in scientific journals.

The instruments of this study include the validation sheet of learning tools to measure the level of conformity or validity between the instructions in the syllabus and the planning of the learning unit. This validation sheet was assessed by experts in the field of power electronics and learning media experts. Performance test sheets are used to measure student practice results while carrying out instructions in the jobsheet. Student response questionnaire sheets are used to measure students' opinions after carrying out instructions in the jobsheet.

Preliminary Analysis

Volume 3, Number 2, November 2020
Revision 


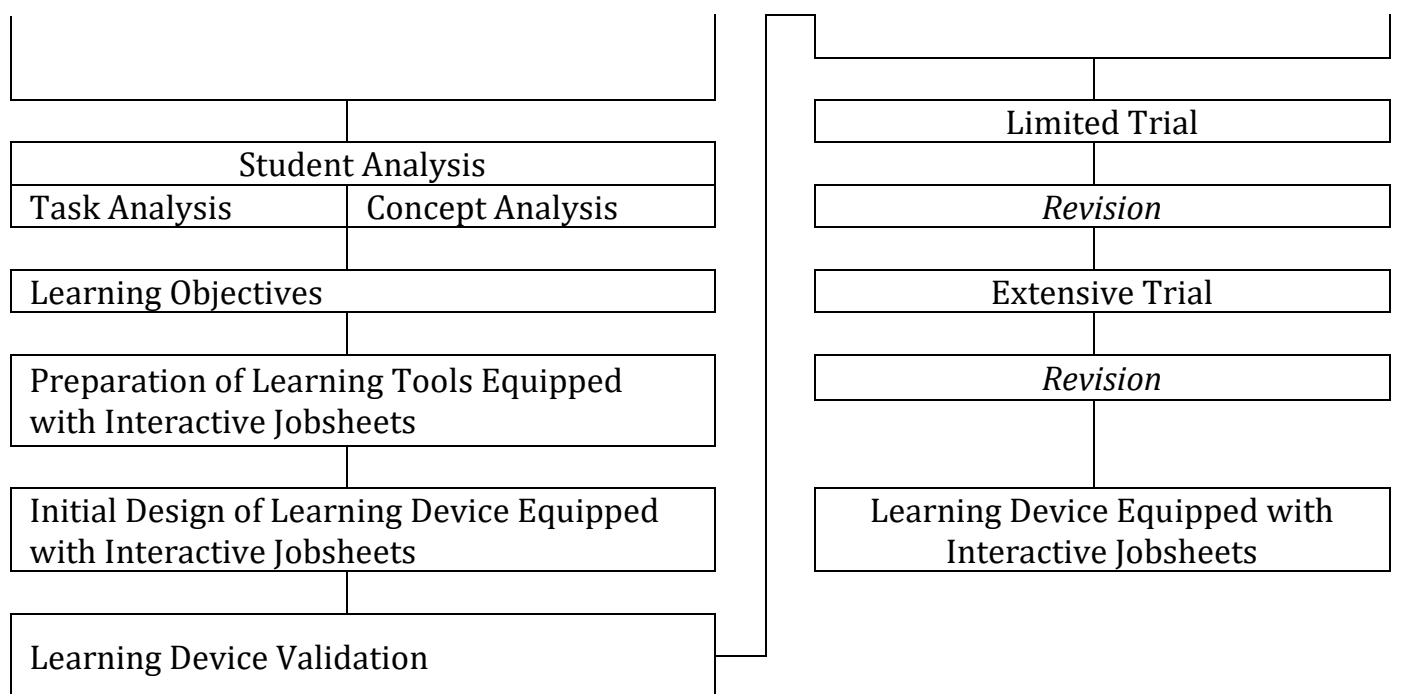

Figure 1. Step of Research on R \& D Model

Data collection techniques in this study include, Validation of learning tools to determine the suitability of the worksheet with the objectives, format, concepts, language, illustrations, evaluation of expert lecturers. Take the results of student performance tests while carrying out the practicum, to see student learning outcomes after using an interactive jobsheet. Taking student responses through student questionnaires to obtain student opinions on interactive jobsheets.

\section{RESULT AND DISCUSSION}

The level of validity of the learning device is measured using a learning device validation sheet by the validator.

Based on the results of the rating rating of the validator of the learning device shows the average gets a good rating (4). The results of the rating of the learning kit shows the percentage of $96 \%$ so it can be concluded that the learning kit is suitable for use in learning activities.

The mastery learning of students during the learning activities of basic subjects electricity and electronics is calculated by taking the average value of the performance test. Student performance test results show an average value of 85.9 out of 30 students who carry out practicum in basic electricity and electronics. So it can be concluded that students get good and complete category performance test results.

The Development of Learning Media Using Interactive Jobsheets for Basic Subjects in Electricity and Electronics Using PSIM in Tamansiswa Vocational High School Hidayat, N., Suprianto, B., \& Hariadi, E. 
Table 1. Result of Students Performance Test

\begin{tabular}{|c|c|c|c|c|c|}
\hline \multirow{3}{*}{$\begin{array}{l}\text { Student } \\
\text { Absence }\end{array}$} & \multicolumn{4}{|c|}{ Performance Test List } & \multirow{3}{*}{$\begin{array}{l}\text { Total } \\
\text { Score }\end{array}$} \\
\hline & $\begin{array}{l}\text { Prepare } \\
\text { the tools } \\
\text { and } \\
\text { software } \\
\text { needed } \\
\text { (25) }\end{array}$ & $\begin{array}{l}\text { Connect } \\
\text { components } \\
\text { according } \\
\text { to the } \\
\text { circuits } \\
\text { (25) }\end{array}$ & $\begin{array}{l}\text { Check } \\
\text { whether } \\
\text { the } \\
\text { component } \\
\text { is installed } \\
\text { correctly } \\
(25)\end{array}$ & $\begin{array}{l}\text { Simulate } \\
\text { the circuit } \\
\text { and produce } \\
\text { a simulation } \\
\text { output on } \\
\text { simview } \\
\text { (25) }\end{array}$ & \\
\hline & 1 & 2 & 3 & 4 & \\
\hline 1 & 22 & 23 & 22 & 22 & 89 \\
\hline 2 & 22 & 22 & 23 & 22 & 89 \\
\hline 3 & 20 & 20 & 20 & 20 & 80 \\
\hline 4 & 20 & 22 & 22 & 22 & 86 \\
\hline 5 & 21 & 22 & 22 & 22 & 87 \\
\hline 6 & 22 & 23 & 23 & 23 & 91 \\
\hline 7 & 22 & 23 & 23 & 22 & 90 \\
\hline 8 & 22 & 23 & 22 & 23 & 90 \\
\hline 9 & 21 & 21 & 22 & 21 & 85 \\
\hline 10 & 20 & 21 & 21 & 21 & 83 \\
\hline 11 & 21 & 21 & 21 & 22 & 85 \\
\hline 12 & 21 & 21 & 22 & 21 & 85 \\
\hline 13 & 20 & 20 & 20 & 21 & 81 \\
\hline 14 & 20 & 21 & 20 & 21 & 82 \\
\hline 15 & 20 & 22 & 22 & 21 & 85 \\
\hline 16 & 20 & 20 & 20 & 21 & 81 \\
\hline 17 & 22 & 22 & 21 & 22 & 87 \\
\hline 18 & 22 & 22 & 22 & 23 & 89 \\
\hline 19 & 21 & 21 & 21 & 21 & 84 \\
\hline 20 & 20 & 21 & 21 & 21 & 83 \\
\hline 21 & 20 & 21 & 20 & 21 & 82 \\
\hline 22 & 20 & 22 & 21 & 21 & 84 \\
\hline 23 & 22 & 23 & 23 & 23 & 91 \\
\hline 24 & 21 & 22 & 23 & 21 & 87 \\
\hline 25 & 22 & 22 & 23 & 23 & 90 \\
\hline 26 & 21 & 22 & 21 & 22 & 86 \\
\hline 27 & 21 & 21 & 22 & 22 & 86 \\
\hline 28 & 21 & 21 & 22 & 23 & 87 \\
\hline 29 & 21 & 23 & 23 & 23 & 90 \\
\hline 30 & 20 & 20 & 21 & 21 & 82 \\
\hline
\end{tabular}

Based on the results of calculations using the t-test on correlated samples for basic subjects electricity and electronics on the pre-test and post-test results. Shows the pre-test score obtained an average learning result of 80 . While the post-test score obtained an average learning outcome of 85. The number of respondents or students as research samples was 30 students. The standard deviation in the pre-test was 3.55 and the post-test was 3.75. Correlation coefficient value is 0.985 . Because the average value of learning outcomes in pre-test $80<$ post-test 85 , then descriptively there is a difference in the average learning outcomes between pre-test and post-test.

Table 2. Result of Experts Validation 


\begin{tabular}{|c|c|c|c|c|c|c|}
\hline \multirow[b]{2}{*}{ Category } & \multicolumn{2}{|c|}{$\begin{array}{l}\text { Scoring } \\
\text { Scale* }\end{array}$} & \multirow[b]{2}{*}{$\begin{array}{c}\text { Number of } \\
\text { Expert } \\
\text { Answers }\end{array}$} & \multirow[b]{2}{*}{$\begin{array}{l}\text { Highest } \\
\text { Experts } \\
\text { Score }\end{array}$} & \multirow[b]{2}{*}{ Rating } & \multirow[b]{2}{*}{$\begin{array}{l}\text { Rating } \\
\text { Results }\end{array}$} \\
\hline & 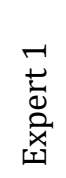 & 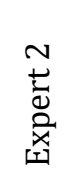 & & & & \\
\hline 1. Foreground & 4 & 4 & 8 & 8 & 1 & $100 \%$ \\
\hline a. Cover & 4 & 4 & 8 & 8 & 1 & $100 \%$ \\
\hline b. Contents & 4 & 4 & 8 & 8 & 1 & $100 \%$ \\
\hline c. Pages number & 4 & 4 & 8 & 8 & 1 & $100 \%$ \\
\hline 2. Syllabus & 4 & 4 & 8 & 8 & 1 & $100 \%$ \\
\hline 3. Lesson Plan & 4 & 4 & 8 & 8 & 1 & $100 \%$ \\
\hline a. Core Competencies & 4 & 4 & 8 & 8 & 1 & $100 \%$ \\
\hline b. Basic Competencies & 4 & 4 & 8 & 8 & 1 & $100 \%$ \\
\hline c. Indicator & 3 & 4 & 7 & 8 & 0,88 & $88 \%$ \\
\hline d. Learning Objectives & 3 & 4 & 7 & 8 & 0,88 & $88 \%$ \\
\hline e. Learning Activities & 4 & 3 & 7 & 8 & 0,88 & $88 \%$ \\
\hline 4. Assessment Sheet & 4 & 4 & 8 & 8 & 1 & $100 \%$ \\
\hline a. LP 1: Cognitive & 4 & 3 & 7 & 8 & 0,88 & $88 \%$ \\
\hline b. LP 2: Psychomotor & 4 & 4 & 8 & 8 & 1 & $100 \%$ \\
\hline 5. Jobsheet & 4 & 4 & 8 & 8 & 1 & $100 \%$ \\
\hline a. Teacher Jobsheet & 4 & 3 & 7 & 8 & 0,88 & $88 \%$ \\
\hline b. Student Jobsheet & 4 & 4 & 8 & 8 & 1 & $100 \%$ \\
\hline 6. Media & 4 & 4 & 8 & 8 & 1 & $100 \%$ \\
\hline Learning Video & 3 & 4 & 7 & 8 & 0,88 & $88 \%$ \\
\hline Average & 3,8 & 3,8 & 7,7 & 8 & 0,96 & $96 \%$ \\
\hline
\end{tabular}

Based on the results of calculations using the t-test on correlated samples for basic subjects electricity and electronics on the pre-test and post-test results. Shows the pre-test score obtained an average learning result of 80 . While the post-test score obtained an average learning outcome of 85 . The number of respondents or students as research samples was 30 students. The standard deviation in the pre-test was 3.55 and the post-test was 3.75. Correlation coefficient value is 0.985 . Because the average value of learning outcomes in pre-test $80<$ post-test 85 , then descriptively there is a difference in the average learning outcomes between pre-test and post-test.

The results of the calculation of the correlated sample t-test obtained a negative result that is $-39,480$. Negative value is caused because the average score of pre-test learning outcomes is lower than the average post-test learning outcomes. In a context like this, the negative $t$ value can be positive. So the value of $t$ will be 39.480 . The value of degrees of freedom (df) of 29 and a significance value of $0.05 / 2$ equals 0.025 . Then the value of $t$ table is 2.045. Thus, because the value of $t$ arithmetic $39.480>t$ table 2.045, it can be concluded that there is an average difference between pre-test learning outcomes and post-tests. This means that there is an influence of the use of learning devices by using interactive jobsheets in improving learning outcomes for basic subjects of electricity and electronics in class $\mathrm{X}$ TKL students.

Based on the results of the rating of respondents' opinions on the basic learning activities of electricity and electronics shows the average gets a very appropriate rating (5). The results of the rating of the learning device shows the percentage of $88 \%$ so it can be concluded that the learning device using an interactive jobsheet helps students carry out learning activities and practicums of basic subjects in electricity and electronics.

The Development of Learning Media Using Interactive Jobsheets for Basic Subjects in Electricity and Electronics Using PSIM in Tamansiswa Vocational High School Hidayat, N., Suprianto, B., \& Hariadi, E. 
Table 3. Result of Students Responses

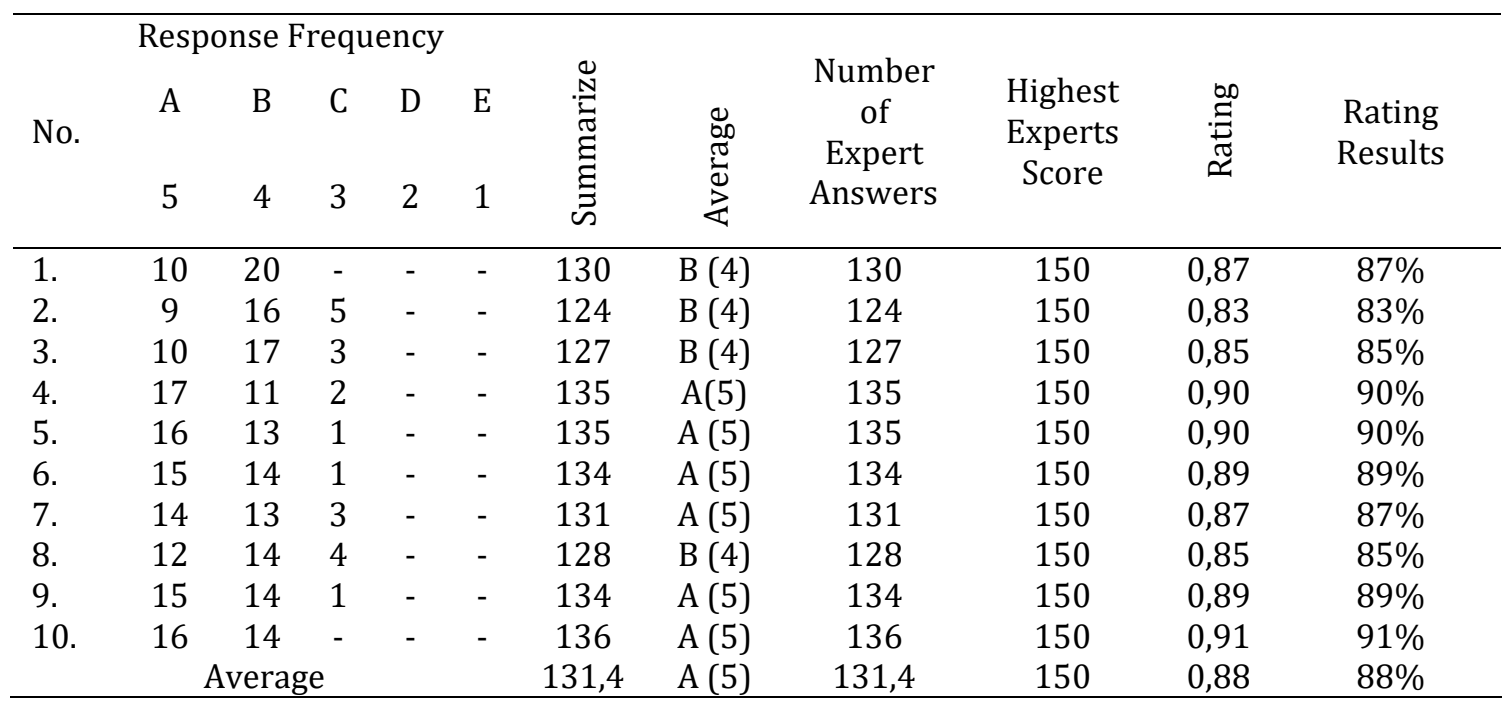

Based on the results of calculations using the t-test on 2 independent samples for basic subjects electricity and electronics on the results of the post-test experimental class and post-test non-experimental class. Shows the post-test scores of the experimental class obtain an average learning outcome of 85 . While the non-experimental class post-test scores obtain an average learning result of 81 . The number of respondents or students as research samples is 60 students, consisting of 30 students experiment and 30 nonexperimental class students. Standard deviation in the experimental class post-test was 3.755 and the non-experimental post-test class was 2.664. Because the average value of learning outcomes in non-experimental class post-test < post-test experimental class, then descriptively there is a difference in average learning outcomes between non-experimental post-test class and post-test experimental class.

The results of independent sample t-test calculations obtained 4,420 results. The value of degrees of freedom ( $\mathrm{df}$ ) of $\mathrm{df}=\mathrm{n} 1-1=29, \mathrm{df}=\mathrm{n} 2-1=29$ and the significance value of 0.05 / 2 equals 0.025 . Then the value of $t$ table is 2.045 . Thus, because the value of tcount $4.420>t$ table 2.045, it can be concluded that there is an average difference between the learning outcomes of post-test experimental class and post-test non-experimental class. This means that the learning outcomes of experimental class students after using interactive jobsheets are better than the learning outcomes of non-experimental class students.

\section{CONCLUSION}

Learning tools in this study show the validation results of the validators with an average value of 4 (good). The results of the assessment rating of learning devices obtained a percentage of $96 \%$ so that it can be concluded that the learning tools using interactive jobsheets of basic subjects of electricity and electronics using PSIM at Tamansiswa Mojokerto Vocational High School are suitable for use in learning activities.

The results of practicum learning for basic subjects in electricity and electronics from 30 students obtained the highest value of 91 . The results of the performance tests of 30 students obtained an average score of 85.9 , so it can be concluded that the results of the student performance tests were in the good category.

Student responses to the use of learning tools in this study on average gave a very appropriate assessment (5). Learning devices equipped with interactive jobsheets can help students to learn and practice basic subjects in electricity and electronics. So the results of 
the learning device rating obtained a percentage of $88 \%$ gives the conclusion that the learning device really helps students learn the material and carry out basic electrical and electronic practicum.

Improved student learning outcomes while using learning tools by using interactive jobsheets are assessed from the results of pre-test and post-test. Students carry out 30 online tests with an average pre-test score of 80 with the highest score of 86 , while an average post-test score of 85 with the highest score of 91 . To obtain the results of a comparison between pre-test and post-test scores Tests carried out t-test samples correlated with the results of the calculation of 39,480, with a value of $t$ table 2.045. Because the value of $t$ arithmetic $(39,480)$ is greater than $t$ table $(2,045)$ so it can be concluded that there is an influence of the use of learning tools equipped with interactive jobsheets in improving student learning outcomes.

The hypothesis of this study is the learning outcomes of experimental class students after using interactive jobsheets is better than the learning outcomes of non-experimental class students. Consisting of two classes, namely one experimental class and one nonexperimental class, the experimental class gets the basic material and practicum of electricity and electronics while the non-experimental class only gets the material. The average score of the experimental class post-test results was 85 , while the average value of the non-experimental class post-test results was 80 . The results of the independent sample $\mathrm{t}$-test obtained 4,420 results, while the $\mathrm{t}$-table value was 2,045 . So the value of $\mathrm{t}$ arithmetic (4.420) is greater than $t$ table (2.045), it can be concluded that the learning outcomes of experimental class students after using interactive jobsheets is better than the learning outcomes of non-experimental class students, the hypothesis can be accepted.

\section{ACKNOWLEDGEMENT}

Thank you to Tamansiswa Vocational High School, Mojokerto, Principal and Electrical Teachers, Head of Technology and Vocational Education Dr. Tri Rijanto, M.Pd., M.T., Expert Validator and Thesis Asessment Team also Editor of the Master of Vocational Education Journal, Ahmad Dahlan University

\section{REFERENCES}

Ashari, Mochamad. (2012). Sistem Konverter DC: Desain Rangkaian Elektronika Daya. Surabaya: ITS Press.

Bakri, Hasrul. (2011). Desain Media Pembelajaran Animasi Berbasis Adobe Flash CS3 Pada Mata Kuliah Instalasi Listrik 2. Jurnal MEDTEK Volume 3 Nomor 2.

Belinda Soo-Phing \& Tse-Kian. (2007). Interactive Multimedia Learning: Student's Attitude and Learning Impact in An Animation Course. The Turkish Online Journal of Educational Technology - TOJET October 2007 ISSN: 1303-6521 volume 6 Issue 4 Article 3, 28-37.

Colon, B., Taylor, K. A., \& Willis, J. (2000). Constructivist Instructional Design: Creating a Multimedia Package for Teaching Critical Qualitative Research. The Qualitative Report, 5(1), 1-29. Retrieved from https:/nsuworks.nova.edu/tqr/vol5/iss1/6.

Fui-Theng \& Mai. (2014). Interactive Multimedia Learning: Innovating Classroom Education in a Malaysian University. TOJET: The Turkish Online Journal of Education Technology, volume 13 issue 2, 99-110.

Girwidz, R , Bogner, F.X. , Rubitzko,T. \& Schaal, S. (2006). Media-assited Learning in Science Education: An Interdiscipliny Appoarch to Hibernation and Energy Transfer. Science Education International. Vol. 17, No.2, 95-107.

\footnotetext{
The Development of Learning Media Using Interactive Jobsheets for Basic Subjects in Electricity and Electronics Using PSIM in Tamansiswa Vocational High School Hidayat, N., Suprianto, B., \& Hariadi, E.
} 
Isman, Aytekin \& Celikli, Gulsun Ersoy. (2009). How Does Student and Self-Efficacy Affect The Usage of Computer Technology. The Turkish Online Journal of Educational Technology - TOJET ISSN: 1303-6521 volume 8 issue 1, 33-38.

Kirkwood, Adrian \& Price, Linda. (2014). Technology-enhanced Learning and Teaching in Higher Education: What is 'Enhanced' and How Do We Know? A Critical Literature Review. Learning, Media and Technology, 39(1), doi:10.1080/ 17439884.2013.770404.

Kurniawan, Wahyu Dwi. (2012). Pengembangan Perangkat Pembelajaran Mekatronika Berbasis Komputer Pokok Bahasan Programmable Logic Controller Berorientasi Pada Pembelajaran Langsung. (Tesis yang tidak dipublikasikan), Universitas Negeri Surabaya, Surabaya.

Lee, Tien Tien \& Osman, Kasimah. (2011). Effectiveness of Interactive Multimedia Module with Pedagogical Agent (IMMPA) in The Learning of Electrochemistry: A Preliminary Investigation. Asia Pacific Forum on Science Learning and Teaching, Volume 12, Issue 12, Article 9, 1-24.

Lee, Tien Tien \& Osman, Kasimah. (2012). Interactive Multimedia Module with Pedagogical Agents: Formative Evaluation. International Education Studies, Vol.5, No.6, doi:10.5539/ies.v5n6p50.

Manongga, Danny dkk. (2009). Perancangan Modul Pembelajaran Berbasis Interactive Multimedia Learning. Jurnal Teknologi Informasi-Aiti, Vol.6 No.1, 16-29.

Mayer, Richard E. \& Moreno, Roxana. (2003). Nine Ways to Reduce Cognitive Load in Multimedia Learning. Educational Psychologist, 38(1), 43-52.

Nopitasari, Fitri \& Purnama, Wawan. (2012). Penggunaan Jobsheet Interaktif dalam Praktikum Analisis Rangkaian Listrik dan Elektronika. Jurnal INVOTEC, Volume VIII, No.2, 137-146.

Tarmizi. (2010). Desain Sistem Kontrol Sudut Penyalaan Thryristor Komutasi Jaringan Berbasis Mikrokontroller PIC 16F877. Jurnal Rekayasa Elektrika,Vol.9 No.1.

Thiagarajan, Sivasaliam, Semmel, Dorothy S., Semmel, Melvyn I. (1974). Instructional Development for Training Teachers of Exceptional Children: A Sourcebook. Minnesota: University of Minnesota.

Wiburg, K., Parra, J., Mucundanyi, G., Latorre, J., \& Torres, R. C. (2017). Constructivist Instructional Design Models Applied To The Design and Development of Digital Mathematics Game Modules. International Journal of Technology in Teaching and Learning, 13(1), 1-15 
The Development of Learning Media Using Interactive Jobsheets for Basic Subjects in Electricity and Electronics Using PSIM in Tamansiswa Vocational High School Hidayat, N., Suprianto, B., \& Hariadi, E. 